\title{
MEMBANGUN KELUARGA UTAMA (MKU) DALAM PEMBERDAYAAN MASYARAKAT MARGINAL STUDI BMT AS SYAFIIYAH, KOTAGAJAH LAMPUNG TENGAH
}

\author{
Aye Sudarto \\ Institut Agama Islam Agus Salim Metro, Lampung \\ Email: ayesudarto18@gmail.com
}

\begin{abstract}
The program description empowers the economy of marginal communities. This requires moral support, meteriel from all parties by providing input to be able to support and improve for the benefit, benefit and welfare of the community. To be able to create prosperity, a society that can support community empowerment requires protection and professional management of the organization. The nature of the economic empowerment program is learning for the community, so that it can be agreed that the main element of empowerment is the development of the economic capacity of the community itself. The series of capacity building in economic empowerment conducted by BMT as Safiiyah consisting of socialization activities, implementation of empowerment, and provision of business capital have been carried out well, by using socio-economics related to social relations and daily life of the community.
\end{abstract}

Keywords : Empowered, Marginal Group, BMT As Safiiyah

\section{DASAR PEMIKIRAN}

BMT As Syafiiyah mempunyai Program pemberdayaan masyarakat marginal yang dikenal dengan konsep Membangun Keluarga Utama (MKU). Dakam Konsep MKU Masyarakat dikelompokkan dalam suatu kelompok yang beranggotakan sampai dengan 10 orang.Masing masing orang dibina untuk berusaha dan dimotivasi dalam kelompok dan dilakukan pertemuan berkala untuk memotivasi dan pembinaan. ( BMT Assyafiiyah, Laporan tahunan tahun 2018)

Setiap orang mendapatkan modal usaha sebesar Rp 500.000,- sampai dengan Rp 3.000.000,- (tiga juta rupiah). Para pengusaha ini mendapatkan modal dan mengembalikan sebesar pokok pinjaman.Pengusaha yang mendapatkan modal dimotivasi untuk berinfak sesuai dengan kemampuannya. Untuk lebih jelasnya dapat dilihat pada tabel 2 di bawah ini: 
Tabel 1: Membangun Keluarga Utama (MKU)

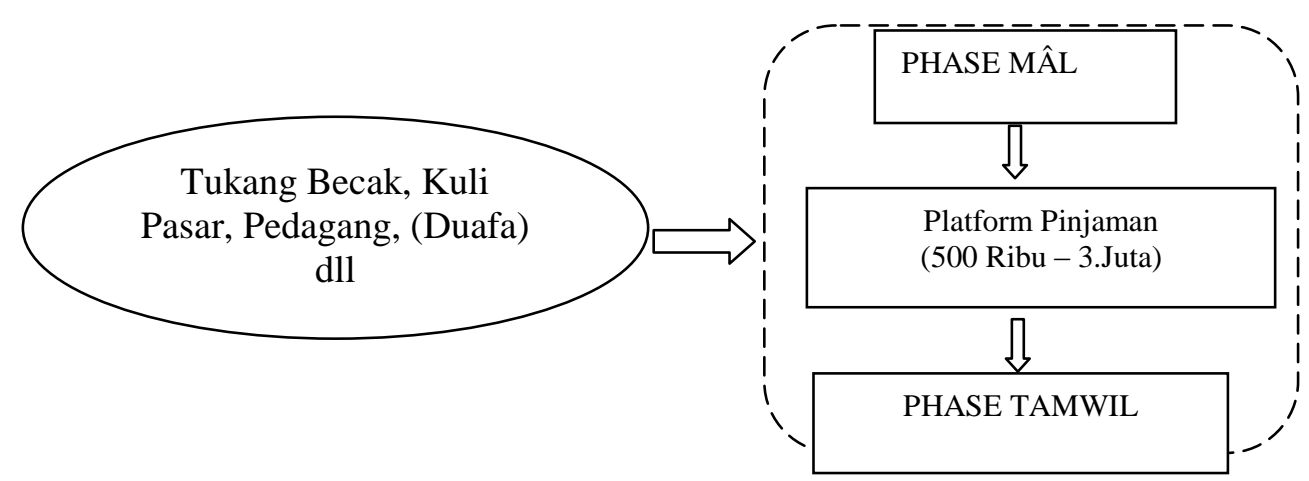

Sumber: Data diolah dari Doc. BMT As Syafiiyah

Proses berusaha pengusaha yang memiliki perkembangan dan kemampuan untuk mengembangkan usahanya menjadi lebih besar dan lebih baik dimotovasi untuk mengembangkan usahanya. Bila sudah mampu untuk mandiri maka pengusaha ini memasuki program pendanaan Tamwil.

Kelesuan perekenomian dunia, kemiskinan ekstrem di dunia terus berkurang, menurut laporan terbaru Bank Dunia terkait isu kemiskinan dan kesejahteraan bersama. Seiring dengan proyeksi tren pertumbuhan, laporan tersebut mengingatkan bahwa pengurangan ketimpangan yang tinggi semakin penting agar tercapai target pengentasan kemiskinan ekstrem di tahun 2030. bahwa di 34 dari 83 negara yang dipantau, kesenjangan pendapatan melebar seiring dengan meningkatnya pendapatan di antara 60 persen terkaya dibanding mereka yang berada di 40 persen termiskin (https://www.worldbank.org/in/news/press-release/2016/10/02/tackling-inequality-vitalto-end-extreme-poverty-by-2030. akses 30 Juli 2019 pukul 20.30).

Strategi tersebut mengungkap kebijakan yang terbukti telah menambah penghasilan masyarakat miskin, memperbaiki akses masyarakat terhadap layanan penting, dan memperkuat prospek pembangunan jangka panjang tanpa merusak pertumbuhan. Kebijakan ini berkinerja baik ketika didampingi oleh pertumbuhan yang kuat, manajemen makro ekonomi yang baik, dan pasar tenaga kerja yang dapat menciptakan lapangan kerja dan memungkinkan masyarakat termiskin untuk memanfaatkan peluang tersebut.

Konsep Al-Qur'an terhadap lembaga ekonomi yang mengandung unsur-unsur: struktur, manajemen, fungsi, hak dan kewajiban. Kalimat kalimat kaum, 
Ekonomica Sharia Volume 5 Nomor 1 Edisi Agustus $2019 \mid 65$

Masyarakat(masyarakat), muluk (pemerintah), balad (negeri), suq (pasar), zakat, sodaqah, ba'i, dain, Mâl dan Iain-lain yang mengindikasikan adanya fungsi dan peran tertentu dalam perkembangan masyarakat ( Muhammad, 2005:21-22 ). Al-Quran secara eksplisit menekankan untuk memberikan sedekah dan zakat untuk orang orang fakir dalam bentuk kisah ataupun perintah. Seperti dalam Surat Al Baqarah ayat 271 dan At Taubah ayat 60 di bawah ini:

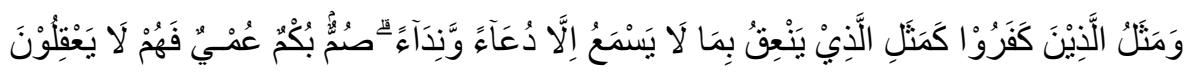

Jika kamu menampakkan sedekah(mu), maka itu adalah baik sekal, dan jika kamu menyembunyikannya dan kamu berikan kepada orang-orang fakir, maka menyembunyikan itu lebih baik bagimu, dan Allah akan menghapuskan dari kamu sebagian kesalahan-kesalahanmu; dan Allah mengetahui apa yang kamu kerjakan. ( Departement Agama, Al quran dan Terjemahan. 2009: 46)

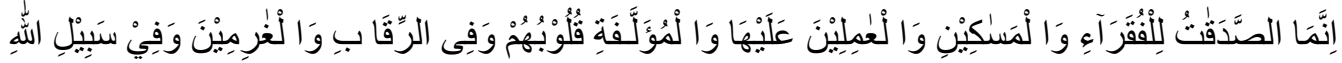

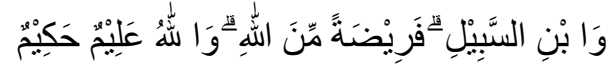

Sesungguhnya zakat-zakat itu, hanyalah untuk orang-orang fakir, orang-orang miskin, pengurus-pengurus zakat, para mu'allaf yang dibujuk hatinya, untuk (memerdekakan) budak, orang-orang yang berhutang, untuk jalan Allah dan untuk mereka yang sedang dalam perjalanan, sebagai suatu ketetapan yang diwajibkan Allah, dan Allah Maha Mengetahui lagi Maha bijaksana ( Departement Agama, Al quran dan Terjemahan. 2009: 196 ).

Kewajiban membayarkan zakat serta sodakoh kepada fakir dan miskin, dikarenakan ketidakmerataan distribusi kekayaan di masyarakat.Zakat dan sodakoh bertujuan untuk mengeliminasi kemiskinan sehingga perlu di susun suatu sistem untuk dapat membebaskan dari lingkaran kemiskinan.Kemiskinan merupakan permasalahan seluruh negara.Pada umumnya kemiskinan di ukur dari tingkat pendapatan dan kebutuhan pokok minimal suatu Negara (Ellies,S, 1994: 132).

Islam melihat kemiskinan dari tiga hal, yaitu: miskin iman, miskin ilmu dan miskin harta. Yang dimaksud dengan miskin iman adalah orang yang jiwanya hanya sedikit kontak dengan Allah. Miskin ilmu adalah: Manusia yang tidak cukup punya ketrampilan dan pengetahuan dalam permasalahan hidupnya. miskin harta adalah: Manusia yang belum dapat memenuhi kebutuhan dasar hidupnya (Ellies,S' 1994: 231-23).

Memperbaiki kondisi ketimpangan distribusi pendapatan serta menanggulangi kemiskinan Islam memberikan langkah taktis sebagai berikut (Qordowi, 1995: 56). 
66 | Aye Sudarto Membangun Keluarga Utama (MKU).....

1. Menggalakkan kerja dikalangan kaum miskin, baik dengan menyemangati maupun dengan cara memberikan lapangan pekerjaan. Kaum miskin harus terus ditingkatkanetos dan semangat kerjanya.

2. Mengusahakan jaminan dari kerabat yang kaya, dimana mereka akan membantu kerabatnya yang miskin.

3. Mengoptimalkan pemungutan dan pendistribusian zakat, agar zakat lebih mampu berdaya guna dalam perekonomian.

4. Menganjurkan sedekah yang sifatnya sukarela.

Pemberdayaan masyarakat marjinal, di perlukan langkah-langkah dan upaya untuk mempersiapkan masyarakat agar dapat mengoptimalkan potensi diri dan dapat berusaha dan komunitas kelembagaan masyarakat berfungsi. Dengan keberfungsian kelembagaan akan mewujudkan kemajuan, kemandirian, dan kesejahteraan dalam suasana keadilan yang berkelanjutan untuk meningkatkan harkat dan martabatnya serta mampu melepaskan diri dari perangkap kemiskinan dan keterbelakangan. Upaya tersebut merupakan salah satu wujud nyata dari pemberdayaan Masyarakat (Sumaryadi, 2005: $111)$.

\section{METODE PENELITIAN}

Agar dapat membantu penulis mencapai sasaran yang tepat maka diperlukan metode. Metode adalah: sebuah rumusan yang terdiri dari sejumlah langkah-langkah yang dirangkaikan dalam urutan-urutan tertentu ( E. Sumaryono, 1993:134 ). Penelitian merupakan suatu kegiatan ilmiah yang berkaitan dengan analisis dan kontruksi dilakukan dengan cara metodologis, sistematik dan kosnsisten. Penelitian ini merupakan penelitian diskriptif-kwalitatif yaitu suatu penelitian yang bersifat pemaparan dan bertujuan memperoleh gambaran (diskripsi) secara utuh.Di uraikan secara rinci jelas dan sistematis.( Sumardi Suryabrata, 1990: 19 ). Yang menjadi objek penelitian adalah: apa dan bagaimana BMT As Syafiiyah dalam melakukan pemberdayaan masyarakat marginal melalui program $M K U$. 


\section{LANDASAN TEORI}

\section{Lembaga Keuangan Pada Awal Islam}

Masyarakat Arab Pra- Islam melakukan hidup secara nomaden dan cukup bergantung dengan sumberdaya alam yang ada. Pengelolaan sumber daya tenaga, ketrampilan, dan kecerdasan yang melekat pada fisik mereka dan juga peternakan. Ketika itu mereka tidak menilai tanah sebagai sumber daya. Mereka bahkan tidak mengenal konsep hak milik, kecuali pada kemah tempat tinggal, barang keperluan pribadi, dan ternak yang dipelihara. Makanan yang tersedia amat sederhana, hanya gandum dicampur dengan sedikit susu dan kurma. Pada masa kering yang berkepanjangan ketika air menjadi sangat langka,perang antar kabilah untuk saling berebut sumber daya ekonomi (rezeki) menjadi tidak terelakkan, sebagai hal yang lumrah dan rutin terjadi. Harta benda boleh dirampas oleh kabilah lain, sepanjang mampu merebutnya dan ini merupakan sebab utama terjadinyaperangantar kabilah. (Aye Sudarto, 2019: 3 )

Muhammad SAW setelah dilantik menjadi Rasul, merasa perlu membuat perkumpulan atau organisasi. Dengan organisasi ini, rencana dakwah dan ekspansinya akan lebih mudah disosialisasikan. Pada tahap awal penyiaran Islam, beliau membentuk Dârul Arqâm. Yakni organisasi dakwa yang di dalamnya dilakukan pengkaderan secara intensif untuk membentuk pribadi muslim yang tangguh. Sentra kegiatan dimulai dari rumah sahabat Arqom bin Abil Arqom Al Makhzumi yang berada di puncak bukit shafa dan terpencil dari pengintaian orang-orang Quraisy. Peristiwa ini terjadi semenjak tahun kelima dari kenabian.(Syaikh Syaifurrahman al Mubarakfiry, 1998: 126 ).

Peristiwa hijrah, semakin memperteguh keyakinan nabi dan para sahabatnya tentang pentingnya sentral kegiatan Masyarakat.Maka nabipun membangun masjid Quba. Masjid ini tidak hanya berfungsi sebagai tempat sholat dan ibadah mahdah lainnya, tetapi lebih luas dari itu, yakni tempat musyawarah urusan masyarakat.Tempat ini juga berfungsi untuk menyatukan antara kaum Muhajirin dan Anshor. Kemudian nabi membangun masjid lain yang lebih besar yakni masjid Nabawi. Masjid ini yang selanjutnya menjadi sentral pemerintahan. Dan yang dibangun nabi Muhammad. S.A.W adalah Pasar.( Aye Sudarto, 1990: 35 ) 
68 | Aye Sudarto Membangun Keluarga Utama (MKU).....

Lembaga Baitul Mâl (rumah dana), merupakan lembaga bisnis dan sosial yang pertama dibangun oleh nabi. Lembaga ini berfungsi sebagai tempat penyimpanan.Apa yang dilaksanakan oleh rasul merupakan proses penerimaan pendapatan (revenue collection) dan pembelanjaan (expenditure) secara transparan dan bertujuan seperti apa yang disebut sekarang sebagai berorientasi kesejahteraan (welfare oriented) (Muhammad,2003: 23 ).

Kehadiran lembaga ini membawa pembaruan yang besar. Dana-dana Masyarakat, baik yang bersumber dari dana sosial dan tidak wajib seperti sedekah, denda (dam), dan juga dana-dana yang wajib seperti zakat, jizyah dikumpulkan melalui lembaga Baitul Mâl dan disalurkan untuk kepentingan Masyarakat.( Muhammad,2003: 66 ). Hakekat hadis dari nabi Muhammad SAW mengenai pemungutan dan pendistribusian kekayaan negara memberikan bentuk kesucian pada Baitul Mâl. Lembaga ini sampai diidentifikasi sebagai lembaga trust (kepercayaan) Masyarakat Islam dengan khalifah sebagai trustee.Ia bertanggung jawab atas setiap sen uang yang terkumpul dan pendistribusiannya. Bagaimanapun dengan terjadi degenerasi di kalangan Masyarakat Islam konsep ini menjadi kabur dan oleh penguasa yang korup, menjadikan Baitul Mâl untuk kepentingan pribadi mereka.(Muhammad Akram Khan, 1993:181).

Baitul Mâl dibagi menjadi tiga (M. Abdul Manan1993:181 ):

a. Baitul Mâl Khas: merupakan perbendaharaan kerajaan atau dana rahasia. Dana ini khusus untuk pengeluaran pribadi raja dan keluarganya, dana pengawal raja serta hadiah bagi tamu-tamu kerajaan.

b. Baitul Mâl: merupakan sejenis bank sentral untuk kerajaan. Namun pola operasionalnya sebatas kepentingan kerajaan seperti mengatur keuangan kerajaan. Model Baitul Mâl ini sistem pengelolaannya sangat sentralsitik. Pengelola tertinggi berada di tangan raja. Di bawah raja terdapat gubernur yang membawahi wilayah propinsi masing-masing.

c. Baitul Mâl Al Islamin: merupakan Baitul Mâl yang berfungsi secara luas untuk kepentingan masyarakat, baik muslim maupun non muslim. Fungsi-fungsi mencakup kesejahteraan seluruh warga tanpa memandang jenis kelamin, ras dan bahkan agama Baitul Mâl jenis ini bertempat di masjid-masjid utama kerajaan. Di pusat dikelola oleh Qâdhi dan di provinsi dikelola oleh rekan Qâdhi. Tugas 
khalifah adalah mengawasi jalannya masing-masing Baitul Mâl, supaya setiap penerimaan dapat dipisahkan sesuai dengan sumbernya dengan penggunaan yang tepat.

Sepeninggal Rasulullah SAW, tradisi yang sudah dibangun oleh nabi diteruskan oleh para pemimpin setelahnya. Tradisi bermusyawarah terlihat ketika pengangkatan Abu Bakar Asyiddiq menggantikan kepemimpinan Islam. Akhirnya mereka sepakat memilih Abu Bakar sebagai pengganti nabi Muhammad SAW (Aye Sudarto, 1993:621). Oleh Abu Bakar, kebiasaan memungut zakat sebagai bagian dari ajaran Islam dan sebagai sumber keuangan negara. Bahkan terjadi peperangan antara sahabat yang taat kepada kepemimpinan beliau melawan orang-orang yang membangkang. Abu Bakar sebagai yang pertama akan memerangi kaum riddah.Tindakan khalifah ini didukung oleh hampir seluruh kaum muslimin.Untuk memerangi kemurtadan (riddah) ini maka dibentuklah sebelas pasukan. Riddah adalah kelompok yang membangkang terhadap perintah membayar zakat dan mengaku sebagai nabi, sehingga semuanya kembali ke jalan yang benar atau gugur di jalan Allah sebagai syuhada (Siti Maryam dkk, 2002: 56).

Lembaga Baitul Mâl semakin mapan keberadaannya semasa khalifar kedua, Umar bin Khattab. Khalifah meningkatkan basis pengumpulan dana zakat serta sumbersumber penerimaan lainnya. Sistem administrasinya sudah mulai dilakukan penerbitan.Umar memiliki kepedulian yang tinggi atas kemakmuran rakyatnya. Pada masa Umar mulai dilakukan penertiban gaji dan pajak tanah.( Syibli Nu'man, 1981:264 ).Untuk mencapai kemakmuran yang merata, wilayah Syiria yang padat penduduknya dinyatakan tertutup untuk pendatang baru. Untuk mengelola keuangan negara, khalifah mendirikan Baitul Mâl .Pada masa Umar mata uang sudah mulai dibuat.( Nouruzzaman Shiddiqi, 1986: 121)

\section{GAMBARAN UMUM BMT AS SAFIIYAH}

Kondisi masyarakat yang banyak terjerat rentenis menggugah rasa keadilan dan empati untuk membantu dan mengentaskan Masyarakat dari keterjeratan dan keterpurukan ekonomi.Tiga serangkai Ali Nur Hamid, Bapak Mudofir dan Bapak K.Hi.ali Nurja menggas untuk menirikan lembaga keuangan yang berbasis non bunga 
70 | Aye Sudarto Membangun Keluarga Utama (MKU).....

sebagai mana yang di gagas MUI di tingkat nasional.( Wawancara dengan bapak Mudofir Pendiri BMT Assyafiiyah tanggal 6 Juli 2014,. Profile, BMt Assyafiiyah tahun $2014)$.

KJKS BMT As Syafiiyah dirintis pada tanggal 03 September 1995 bertempat do pondok Pesantren Nasional As Syafiiyah Kota Gajah Kabupaten Lampung Tengah. Pendirian KJKS BMT As Syafiiyahdi motori oleh Mudofir, Drs Ali Nurhamid, M.Sc, KH. Suhaimi Rais dan Ali Yurja Syarbani(Wawancara dengan bapak Mudofir Pendiri BMT Assyafiiyah tanggal 6 Juli 2014,. Profile, BMt Assyafiiyah tahun 2014 ).

Berawal dari kegiatan jamah pengajian As Syafiiyah dan pengajian akbar pondok Pesantren Nasional As Syafiiyah dengan penceramah KH. Drs Agus Darmawan dari Jakarta dan menyisihkan dana sebesar Rp 800.000,- (delapan ratus ribu rupiah) yang selanjutnya digunakan sebagai modal awal KJKS BMT As Syafiiyah.

Untuk menambah modal kegiatan layanan, Baitul Mal, BMT As Syafiiyah mendapatkan bantuan dana sebesar $\mathrm{Rp} 2.500 .00$,- (dua juta limaratus ribu rupiah) sebagai dana bergulir dari Bank Muamalat Indonesia. Pada tahun 1999 BMT As Syafiiyah mendapatkan program Lembaga Ekonomi Produktif Masyarakat Mandiri (LEPMM) dari Kementerian Koperasi dan Pembinaan Usaha Kecil (PKK).

Sejarah dan Perkembangan BMT As Syafiiyah

Pada tanggal 15 Maret 1999 mendapat status badan hukum koperasi nomor: 28/BH/KDK.7.2/III/1999. Pada Tanggal 10 September 2004 terbit surat Keputusan Menteri Kperasi nomor: 91/kep/M/KUKM/IX/2004 tanggal 10 September 2004 terkait Koperasi Jasa Keuangan Syariah maka BMT As Syafiiyah menyesuaikan nama menjadi KJKS BMT As Syafiiyah.

\section{HASIL PENELITIAN}

\section{Pemberdayaan Ekonomi Masyarakat Marginal}

Pada hakikatnya pemberdayaan ekonomi Masyarakat merupakan proses peningkatan ekonomi dan pengembangan usaha dengan meningkattkan skil dan jwa kewirausahaan bagi para pengusaha dan calon pengusaha. Hal ini merupakan pembelajaran bagi Masyarakat dan BMT untuk memulihkan dan melembagakan kembali modal sosial (socialcapital) yang telah ada untuk membangun tatanan 
Ekonomica Sharia Volume 5 Nomor 1 Edisi Agustus 2019 71

masyarakat madani yang mampu mandiri dan berkelanjutan menangani kegiatan penanggulangan kemiskinan yang dilaksanakan melalui pengembangan kemampuan berusaha Masyarakat.

Kegiatan pengembangan kapasitas berusaha tersebut dilaksanakan dalam bentuk sosialisasi sosialisasi, pelatihan-pelatihan (coaching) pengajian dan pelaksanaan pemberdayaan dan pemberian modal berusaha.Rangkaian kegiatanpengembangan kapasitas dalam rangka program pemberdayaan ekonomi Masyarakat tersebut telah dilaksanakan seluruhnya di BMT.

\section{Refleksi Kemiskinan}

BMT As Syafiiyah melihat kondisi Masyarakat yang kesulitan untuk memiliki usaha dan akses permodalan bagi kelompok-marginal, membuat solusi-solusi program yang dapat membantu dan dapat mengentaskan Masyarakat dari faktor kemiskinan. Kegiatan yang dilakukan dengan membentuk Baitul Mâl.Hal ini sesuai dengan misi lembaga keuangan dalam Islam, yang tidak hanya mencari keuntungan saja tetapi juga harus memberikan hak-hak kepada kauam Miskin.

BMT As Syafiiyah melalui Baitul Mâlnya membetuk Program Membangun Keluarga Utama. Dimana program ini memberikan modal usaha kepada masyarakat miskin dan kurang mampu tanpa margin sebagaimana kridit komersial.Untuk dapat memastikan usahanya berjalan dengan baik sesuai dengan yang di harapkan mereka mendapatkan dampingan dan bimbing management dan pembukuan yang baik sehingga pengusaha dapat mengembangkan usahanya dengan menegament modern.

Sebagai lembaga sosial Baitul Mâl memiliki kesamaan fungsi dan peran dengan lembaga amil zakat.Baitul Mâl sebagai lembaga yang mengelola dana-dana sosial dandana Masyarakat maka perlu untuk mengelola program dengan profesional agar dana dapat maksimal di guanakan oleh Masyarakat dan tepat sasaran. Salah satu pemanfatan dana ini adalah dengan mengoptimalkan dalam bantuk usaha. Dalam memilih usaha Baitul Mâl mengkhususkan peruntukan untuk kelompok miskin dan marginal. Dalam memanfaatkan dana ini pengusaha tidak di bebani oleh margin. Fokusnya adalah bagamana usaha dapat berjalan dengan baik dengan dampingan management dari Baitul Mâl. 
72 | Aye Sudarto Membangun Keluarga Utama (MKU).....

Indikator yang disepakati untuk mengidentifikasi kemiskinan adalah Sidik, amanah, fathonah, dan tabligh.Termasuk dalam kategori dhuafa sesuai dengan penilaian yang telah ditentukan.Memiliki keinginan kuat untuk bangkit dan mandiri usia produktif.Diutamakan memiliki potensi usaha, berupa: keahlian, akses perlengkapan dan peralatan usaha dan sumber daya lingkungan, siap untuk dibina. Ditinjau dari aspek pengembangan kapasitas, ekonomi Masyarakat bisa mendapatkan banyak pembelajaran dari kegiatan refleksi kemiskinan ini, dimana mereka mendapatkan banyak cerita dan pengalaman mengenai agenda penanggulangan kemiskinan dari tema tema yang disampaikan, serta dapat bertukar pikiran dengan pendamping maupun sesama warga terutama dalam menyampaikan pandangan-pandangannya mengenai kondisi kemiskinan dan kondisi sosial ekonomi lainnya serta kondisi usaha. Melalui rangkaian kegiatan pengusaha merasa dapat mencurahkan pemikirannya secara bebas, apalagi kegiatan tersebut dikemas dalam suasana yang tidak begitu formal.

Keterkaitannya dengan teori mengenai elemen-elemen pengembangan kapasitas, maka dalam kegiatan refleksi kemiskinan ini terdapat proses untuk mengembangkan jiwa altruism atau mengutamakan kepentingan umum, aspek common values atau pengakuan terhadap kesamaan nilai dalam komunitas Masyarakat, dan aspek unity atau kebersamaan dalam kehidupan di komunitasnya.

\section{Pemetaan Keswadayaan Masyarakat}

Rangkaian kegiatan dalam pemberdayaan yang kedua adalah Pemetaan Swadaya.Kegiatan Pemetaan Swadaya dilakukan untuk mendapatkan gambaran kondisi Masyarakat, kondisi kemiskinan, potensi yang dimiliki Masyarakat serta peluang, hambatan dan ancaman yang ada dalam mengatasi masalah-masalah kemiskinan dan masalah lingkungan. Pelaksanaan pemetaan swadaya pada lingkungan BMT As Syafiiyah di lakukan oleh Baitul Mâl wat Tamwil. Hasil Pemetaan Swadaya adalah berupa data-data kondisi ekonomi Masyarakat, permasalahan kemiskinan di masyarakat lingkungan BMT, potensi yang dimiliki masyarakat dan karakteristik ekonomi masyarakat miskin.

Hasil pemetaan permasalahan kemiskinan didapatkan tiga komponen daftar kebutuhan Masyarakat, yaitu komponen yang berkaitan dengan modal usaha, terkait 
Ekonomica Sharia Volume 5 Nomor 1 Edisi Agustus 2019|73

kemmapuan dan skil berusaha (trust) rencana pengembangan dan peningkatan SDM.Komponen yang berkaitan dengan pembangunan usaha produktif yang terdiri dari bantuan modal usaha dan komponen yang berkaitan dengan rencana pengembangan kegiatan sosial dan peningkatan SDM. Keterkaitannya dengan teori pemberdayaan, maka pada tahapan ini Masyarakat sudah melewati tahap melepaskan halanganhalangan atau faktor-faktor yang bersifat resistensi terhadap kemajuan dalam dirinya atau komunitasnya dan tahap merasa menerima kebebasan tambahan dan tanggung jawab yang lebih besar. Melepaskan halangan yang dimaksud yaitu pemahaman Masyarakat terhadap hal-hal apa saja yang selama ini menjadi hambatan dalam pengembangan diri dan komunitasnya untuk kemudian mengidentifikasi potensi dan peluang apa saja yang bisa digunakan untuk melepaskan halangan-halangan yang ada. Dengan adanya hasil pemetaan swadaya yang berupa daftar kebutuhan ekonomi Masyarakat baik yang berkaitan dengan fisik lingkungan, pengembangan ekonomi Masyarakat.

\section{Sinergi dengan Stake Holder}

Keberlanjutan dan keberhasilan program pemberdayaan ekonomi Masyarakat sangat bergantung kepada dukungan Masyarakat dan stake holder Masyarakat, untuk itu BMT harus juga mendapatkan dukungan yang optimal dari semua komponen Masyarakat. Kerjasama dengan pihak swasta, pemerintah dan mitra lain, dan instansi lain juga belum terlaksana dengan maksimal karena masih terbatasnya akses dan kemampuan negosiasi serta kesempatan dan posisi tawar yang dimiliki BMT untuk melakukan kerjasama dengan pihak-pihak eksternal tersebut. Baitul MâllAs Syafiiyah telah menjalin kerjasama dengan Badan wakaf Indonesia (BWI), Dompet Duafa, dan Lampung Peduli. Dengan BWI Baitull Mâl ditunjuk sebagai Nazir Wakaf.Baitull Mall saat ini sedang mengembangkan program Wakaf Uang.Wakaf uang adalah wakaf berupa uang yang dapat dikelola secara produktif, hasilnya dimanfaatkan untuk mauquf alaih.( Nazir Wakaf BMT L Risma, Tanya Jawab Wakaf Uang, 2009: 02 ).

Keberadaan dompet duafa, baru pada tahapan pelatihan pelatihan penguatan dalam pengelolaan zakat. Dengan kegiatan kegiatan ini akan menciptakan pengelola zkat yang profesional. Disamping hal tersebut, dengan disahkannya UU Zakat no 23 tahun 
74 | Aye Sudarto Membangun Keluarga Utama (MKU).....

2011Lihat, ( UU Zakat no 23 tahun 2011 ). mengharuskan Amail zakat dan lembaga zakat lokal menginduk kepada lembaga zakat nasional.( Yusuf Wibisono, 2015:217 ). Diantar lembaga zakat Nasional yang diakui adalah Dompet Duafa. Maka Baitul Mâl Asyafiiyah dalam proses mendapatkan pengakuan sebagai amil zakat dibawah Dompet Duafa.

Kedua Baitul Mâl juga bersinergi dengan Lampung Peduli sebagai sesama pengelola zakat.Sinergi program dilakukan diantaranya berupa pelatihan pelatihan, diantara pelatihan penguatan kelembagaan dan pengelolaan zakat serta pelatihan pembuatan pakan ternak kepada pengusaha ternak, dalam binaan kedua Baitul Mâl.(BMT Assyafiiyah, 2018 ). Pada tahapan ini BMT telah sampai pada tahap pendayaan dari pemberdayaan yaitu pencapaian hasil dan target yang lebih besar. Dengan adanya peluang kerjasama dengan pihak luar, maka Baitul Mâl dapat merencanakan program- program dengan lingkup dan target sasaran yang lebih luas dari yang sebelumnya karena adanya tambahan dukungan dan sumber daya untuk mencapai target yang diharapkan.

Aspek pengembangan kapasitas yang didapatkan Masyarakat adalah meningkatnya akses terhadap informasi terutama dari pihak-pihak eksternal, meningkatnya jaringan kerja (networking) sehingga dengan jaringan yang tercipta Masyarakat bisa mengoptimalkan potensi dan sumber daya yang ada serta dapat meminimalkan halangan-halangan yang selama ini dihadapi. Aspek pengembangan kapasitas yang lain adalah meningkatnya skill sehingga masyarakat melalui BMT memiliki nilai kemampuan yang lebih tinggi dalam pengambilan peran dalam peningkatan usaha dan pemenuhan kesejahteraan keluarga.

Kedua Baitull Mâl perlu untuk lebih banyak lagi melibatkan stake holder Masyarakat. Terutama akses kepada perusahaan perusahana yang ada di lingkungan Baitul Mâl.Karena selama ini CSR belum tergali lebih optimal, dan belum dirasa kemanfaatan untuk Masyarakat.Pendekatan dalam Pengembangan Kapasitas Ekonomi. Upaya dan pendekatan yang dilaksanakan dalam mengembangkan kapasitas ekonomi Masyarakat yang dilakukan BMT Asyafiiyah adalah melalui pendekatan pemberian modal usaha kepada kelompok marginal dan miskin untuk dapat berusaha dan dapat mengembangkan usaha dengan baik dan prosfektif. Dalam pemberdayaan dan 
pembinaan agar dapat berkembang dengan yang diharapkan.Setiap pengusaha dalam pemberdayaan dan pembinaan BMT di kelompokkan.Setiap kelompok berjumlah 10 pengusaha, berdasarkan teritorial tempat dan kedekatan jangkauan.

Penguatan kapasitas yang dilakukan berupa pertemuan rutin, setiap minguuan, tengah bulanan dan bulanan.Dalam karaktristik masyarakat pedagang pengusaha pertemuan pertemuan dapat efektif dilakukan setelah berdagang.Materi pertemuan diantaranya adalah terkait Ibadah.Seperti sholat duha, sholat jamaah dan infaq dan sodaqoh.Pada pertemuan pertemuan tersebut diberikan pematerian terkait motivasi berusaha, skil berusaha dan pengembangan usaha.Keahlian usaha diantaranya adalah terkait service pelayanan, untuk meningkatkan penjualan.Serta management keuangan.Dengen materi menegent keuangan pengusaha diarahkan untuk dapat mengelola usahanya dengan menegement modern.Dimana pengusaha dapat mengelola usaha dengan memisahkan harta usaha dan harta keluarga.

Pengembangan kapasitas Masyarakat di nyatakan berhasil bila telah meningkat amal ibadah, peningkatan pendapatan, eksistensi usaha, terhimpunnya ZIS para penguasa peserta program dan kesadaran Masyarakat dalam membayar zakat infak dan sodaqoh.Indikator yang telah ditetapkan kedua lembaga Mâl ini telah menunjukkan indikasi keberhasilan program. Terutama terkait program infak dan sedakah dari peserta program. Hal ini dapat dilihat dari meningkatnya jumlah penghimpunan danaBaitul Mâl yang dilakukan.

Tabel: 2, Penghimpunan Dana Baitul Mâl As Syafiiyah

\begin{tabular}{|c|l|c|c|c|}
\hline No & Sumber Dana & 2017 & 2018 & Prosentase \\
\hline 1 & Zakat & $126,038,000$ & $116,345,250$ & $-7.69 \%$ \\
\hline 2 & Infak & $872,096,750$ & $1,100,464,650$ & $26.19 \%$ \\
\hline 3 & Shodaqoh & $41,698,400$ & $96,670,900$ & $131.83 \%$ \\
\hline & Jumlah & $1,039,978,750$ & $1,313,480,800$ & $26.30 \%$ \\
\hline
\end{tabular}

Data diolah. Dari laporan BMT Assyafiiyah tahun 2018

Baitull Mâl As Syafiiyah meningkat 26,30\%. Namun bila dilihat dari sumber pendapatan baru terfokus pada hasil zakat dan infak internal yaitu zakat lembaga, kreditor pada kedua Baitultamwil dan peserta program. 
76 | Aye Sudarto Membangun Keluarga Utama (MKU).....

Pelaksanaan dan Pemantauan

Program pemberdayaan Masyarakat melalui MKU dilaksankaan untuk membrikan jalan dan meningkatkan usaha dan kemampuan berusaha kelompok marginal dan miskin dikalangan Masyarakat.Selama ini belum banyak tersentuh dan dimaksimalkan.Kendala usaha kecil dan mikro dari kaelompok Masyarakat ini adalah usaha yang tidak bankable.Dimana usaha yang tidak layak untuk dibiayai oleh lembaga keuangan komersial.

Baitul Mâl didirikan Nabi Muhaamd semenjak awal sejarah Islam. Baitul Mâl pada awal Islam berfungsi sebagai lembaga lembaga penyimpanan dan penerimaan dana Masyarakat yang dilakukan secara transparan yang bertujuan untuk kesejahteraan Masyarakat. Keberadaan lembaga Baitul Mâl mengarahkan kepada pengelolaan dana dana sosial dan wajib seperti sedekah, denda (daam), Zakat, Jisyah. Dana dana tersebut dikelola dan disalurkan untuk kesejahteraan Masyarakat. Begitu juga pada zaman setelah Nabi Muhammad, Baitul Mâl di kelola semakin maju dan secara administrasi lebih tertib.Pada Masa Umar sistem penggajian di tertibkan.Melalui Baitul Mâl para pemimpin Masyarakat Islam mengentaskan kemiskinan Masyarakat dan mambangun sistem moneter yang bermuara pada kesejahteraan Masyarakat.

Lembaga keuangan Syariah tidak hanya sekedar mengejar untung, namun juga berorentasi pada kesejahteraan dan keadilan untuk pemerataan dan keadilan bersama. Dalam bidang pemberdayaan ekonomi resiko sosial terkait ketidak adilan ekonomi ketimpangan dan kemiskinan akan di minimalisir dengan keberdayaan dan optimalisasi usaha dan potensi Masyarakat, melalui kelembagaan keuangan yang di bangun bersama.Sistem Ekonomi Islam pada beberapa hal merupakan jalan tengah antara sistem kapitalis dan sosialis. Sistem ekonomi islam memiliki kebaikan kebaikan yang di punyai kedua sistem ekonomi tersebut. Namun bebas dari kelemahan kelemahan yang dimilki kedua sistem tersebut.Sistem ekonomi Islam memberikan setiap individu kemudahan dalam ekonomi sosial juga memberikan solusi moral tertentu yang membuat tiap individu untuk peduli dan membantu sesamanya.

Penumpukan kekayaan oleh sekelompok orang di hindarkan dan langkah-langkah untuk pendistribusi kekayaan. Secara tegas dinyatakan dalam al-Qur'an menyebutkan 
bahwa didalam harta yang bertumpuk itu terdapat hak orang lain. Sebagaimana di tegaskan dalam kitab Al Quran surat 9. At Taubah ayat 103:

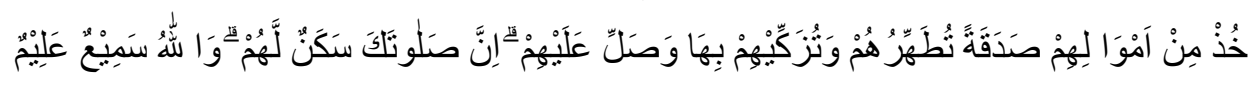

Ambillah zakat dari sebagian harta mereka, dengan zakat itu kamu membersihkan dan mensucikan mereka dan berdoalah untuk mereka. Sesungguhnya doa kamu itu (menjadi) ketenteraman jiwa bagi mereka. dan Allah Maha mendengar lagi Maha Mengetahui.( Departemen Agama, Al Quran Terjemah, Tahun 2009 Surat Al Baqarah hal. 297 ).

Baitul Mâl sebagai lembaga tertua dalam Islam membuka jalan bagai kaum duafa untuk tetep berkembang, BMT merupakan lembaga keuangan yang usaha pokoknya adalah menerima dan menyalurkan dana Masyarakat yang bersifat non komersial dan isntitusi lembaga keuangan yang usaha pokoknya penghimpunan dana pihak ketiga dan membrikan pembiayaan kepada usaha produktif yang menguntungkan.Tahap pelaksanaan program adalah tahapan dimana Baitul Mâl bersama dengan pengusaha yang tergabung dalam program pemberdayaan mengimplementasikan program-program yang telah mereka susun sebagaimana yang tercantum dalam dokumen dan rencana kerja.Tahap pelaksanaan dan pemantauan ini terdiri dari perencanaan usaha, penambahan modal usaha, pertemuan pertemuan dalam kerangka pengembangan usaha dan meningkatanan sahsyiah keagamaan monitoring dan pelaporan.

Program pemberdayaan ekonomi Masyarakat yang dilakukan Baitul Mâl As Syafiiyah dengan program Membangun Keluarga Utama (MKU). Program berbentuk pemberian bantuan modal usaha, akad yang digunakan Qordh.(Muhammmad Safii Antonio, 1999: 185 ).Qordh adalah pemberian harta kepada orang lain yang dapat ditagih atau diminta kembali, dengan kata laian meminjamkan tanpa mengharapkan imbalan, Qordh merupakan dikatagorikan aqad tathowwui atau akad saling bantumembantu dan bukan transaksi komersial. Dalam pelaksanaan program setiap penguasaha di kelompokkan sesuai dengan teritori dan kedekatan tempat usaha dengan jumlah 5 sampai 10 orang yang dibentuk untuk mengatasi permasalahan anggota kelompok secara bersama-sama dalam rangka penanggulangan kemiskinan, sekaligus sebagai pelaksana kegiatan di lapangan program-program yang telah direncanakan. Pembinaan dilakukan secara rutin dengan materi pembinaan terkait Ibadah, serta materi 
78 | Aye Sudarto Membangun Keluarga Utama (MKU).....

terkait pengembangan usaha.Materi Ibadah diantaranya adalah sholat, infaq dan sodaqoh. Materi keahlian usaha terkait services pelayanan peningkatan purna jual dan menegement usaha dan keuangan.

Selama pelaksanaan kegiatan, fungsi monitoring dilaksanakan oleh segenap anggota kelompok dan pendamping.Monitoring dilakukan terkait kesadaran beribadah, menghadiri pertemuan dan melakukan uasaha.Sesama anggota kelompok saling mengingatkan untuk kesadaran berinadah dan beramal soleh.Tahap pelaksanaan ini bisa dikatakan sebagai tahap pemberdayaan yang sesungguhnya, dimana kelompok pengusaha yang terbentuk benar benar diberdayakan untuk melaksanakan program dan kegiatan yang hasilnya adalah untuk kepentingan mereka sendiri, dengan penerima manfaat utama yaitu pengusaha micro kecil, yang uashanya tidak bankable.

Pelaksanaan kegiatan tersebut, anggota kelompok setiap pertemuan di anjurkan untuk berinfaq. Infaq tersebut, diharapkan perekonomian dapat berkembang dan maju, karena uang Mâl akan berkembang dan dapat membantu penguasa micro yang laian yang sangat membutuhkan. Ditinjau dari aspek pengembangan kapasitas, maka pelaksanaan kegiatan pemberdayaan ekonomi Masyarakat ini mengajarkan Masyarakat untuk mengembangkan altruism yaitu mengutamakan kepentingan umum, communal service atau melayani masyarakat terutama warga miskin, mengembangkan keterampilan berorganisasi, mengembangkan kepercayaan masyarakat (trust), mengembangkan keahlian (skills), dan dapat meningkatkan kesejahteraan masyarakat (wealth)

Konsepsi pemberdayaan ekonomi Masyarakat yang dilakukan BMT Assyafiiiyah melalui Baitulmal As Syafiiyah, dengan menggunakan prgram Membangun Keluarga Utama (MKU). Prosedur pembiayaan akad Qord dengan besaran platfom Rp 500.000,sampai dengan Rp 3.000.000,- Penggunaan dana yang dilakukan Baitul Mâl As Syafiiyah secara umum tidak hanya untuk usaha produktif, tetapi juga untuk keperluan konsumtif. Program yang sudah dilakukan Baitul Mâl As Syafiiyah terlihat mengalami kenaikan dan trenpositif. Bila dibandingkan dengan tahun 2013 kenaikan penyaluran dana Mâl mengalami kenaikan sebesar 25,80\%. Dana yang digunakan untuk program Qordul Hasan kenaikan sebesar 14,43\%. 
Tabel: 3, Penyaluran dana Baitull Mâl As Syafiiyah

\begin{tabular}{|c|l|c|c|c|}
\hline No & Penyaluran Dana & 2017 & 2018 & Prosentase \\
\hline 1 & Qordul Hasan & $68,315,000$ & $879,171,000$ & $14.43 \%$ \\
\hline 2 & $\begin{array}{l}\text { Sumbangan } \\
\text { Santunan }\end{array}$ & $84,253,500$ & $114,511,000$ & $35.91 \%$ \\
\hline 3 & $\begin{array}{l}\text { Bantuan Biaya } \\
\text { Sekolah }\end{array}$ & $54,247,000$ & $100,727,000$ & $85.68 \%$ \\
\hline 4 & Bakti Sosial & $65,703,000$ & $97,422,500$ & $48.28 \%$ \\
\hline & Jumlah & $947,418,500$ & $1,191,831,500$ & $25.80 \%$ \\
\hline
\end{tabular}

Data diolah. Dari laporan BMT Assyafiiyah tahun 2018

Jumlah pengusaha yang diberdayakan sebanyak 304 orang dan mengalami kenaikan sebesar 16,92\% bila dibandingkan dengan tahun sebelumnya.

Tabel: 4, Jumlah Pengusaha terberdayakan Baitull Mâl As Syafiiyah

\begin{tabular}{|c|l|c|c|r|}
\hline No & \multicolumn{1}{|c|}{ Program } & Tahun 2017 & Tahun 2018 & Prosentase \\
\hline 1 & Tahap I & 76 & 86 & $13.16 \%$ \\
\hline 2 & Tahap II & 60 & 67 & $11.67 \%$ \\
\hline 3 & Tahap III & 90 & 100 & $11.11 \%$ \\
\hline 4 & Fhase Tamwil & 34 & 51 & $50.00 \%$ \\
\hline & & 260 & 304 & $16.92 \%$ \\
\hline
\end{tabular}

Data diolah. Dari laporan BMT Assyafiiyah tahun 2018

Pemberdayaan usaha kecil micro yang dilakukan Baitul Mâl As Syafiiyah telah mengalami kemajuan yang cukup baik. Ini dapat dilihat dari kenaikan tiap tahapan program, kesemuanya menunjukkan tren kenaikan.Sebagaimana dalam tabel di atas.

\section{KESIMPULAN}

Hakikat program pemberdayaan ekonomi adalah pembelajaran bagi masyarakat, sehingga bisa dikatakan bahwa elemen utama dari pemberdayaan adalah pengembangan kapasitas ekonomi Masyarakat itu sendiri. Rangkaian pengembangan kapasitas dalam pemberdayaan ekonomi Masyarakat yang dilakukan BMT As Syafiiyah yang terdiri dari kegiatan sosialisasi, pelaksanaan pemberdayaan, dan pemberian modal usaha telah 
80 | Aye Sudarto Membangun Keluarga Utama (MKU).....

dijalankan dengan baik, dengan menggunakan pendekatan sosio-ekonomi yaitu dengan memperhatikan aspek keagamaan dan kebiasaan sehari-hari masyarakat.

Proses pemberdayaan yang dilakukan telah sesuai dengan tahapan pemberdayaan yang ditentukan dalam program BMT As Syafiiyah maupun dengan literatur- literatur mengenai pemberdayaan ekonomi. Sedangkan temuan hasil pemberdayaan ekonomi menunjukkan bahwa proses pemberdayaan ekonomi yang telah berjalan selama 2 tahun telah berhasil mengubah tingkat kesadaran Masyarakat dan meningkatkan pemahamannya untuk turut serta berperan dalam pemberdayaan ekonomi di komunitasnya, namun untuk mencapai tingkat kemandirian dan derajat keberdayaan yang sesungguhnya masih diperlukan pembelajaran lebih lanjut yang harus dilakukan secara kontinyu dan terpadu. 


\section{DAFTAR PUSTAKA}

Anggito Abimanyu, "Pemulihan Ekonomi Indonesia dan Pemulihan Ekonomi Masyarakat”,dalam Amin Abdullah, dkk., Meretas Jalan Baru Ekonomi Muhammadiyah, Yogyakarta: PT.Tiara Wacana: 2000

Abdul Munir Mulkhan, "Moral Kenabian: Paradigma Intelektual Pembangunan", dalamAmin Abdullah, dkk.,Meretas Jalan Baru Ekonomi Muhamadiyah, Tiara Wacana,Yogyakarta: 2000

Ahmad Muhammad al-'Assal, al-Nidham al-Iqtishad fi al-Islam: Mabadiuhu Wahdafuhu, terj. Imam Syaifudin,: Pustaka Setia, Bandung: 1999

Aye Sudarto, Lembaga Keuangan Syariah, Purnama Jaya 2018 , Peradaban Ekonomi Islam, Purnama Jaya 2019

BMT Assyafiiyah, Laporan tahunan tahun 2018

Departement Agama, Al quran dan Terjemahan. 2009

Depdiknas, Kamus Besar Bahasa Indonesia, Edisi Ketiga,: Penerbit Balai Pustaka Jakarta :2003

Kementerian Pendidikan Nasional, Kamus Besar Bahasa Indonesia (KBBI), https://kbbi.web.id/daya

E. Sumaryono, Hermeneutik Sebuah Metode Filsafat, Kanisius, Yogyakarta: 1993

Ellies,S. The Dimension of Proverty Kumarian Press. Jakarta:1994

Gunawan Sumodiningrat dan Riant Nugroho D, Membangun Indonesia Emas, Media Komputindo, Jakarta: 2005

https://www.worldbank.org/in/news/press-release/2016/10/02/tackling-inequality-vitalto-end-extreme-poverty-by-2030.

Hairi Firmansyah, Jurnal Agrobisnis Pedesaan, Fak.Pertanian Unlam, Banjar Baru, Vol.02 Nomor 02 Juni 2012

I Nyoman Sumaryadi, Perencanaan Pembangunan Daerah Otonom dan Pemberdayaan Masyarakat, Penerbit Citra Utama, Jakarta: 2005

Idri, M.Ag, Hadis Ekonomi, Prenada Media Group, Jakarta: th 2015

Nouruzzaman Shiddiqi, Tamadun Muslim Bulan Bintang, Jakarta: 1986

Nur Mahmudi Isma'il, "Strategi Pemberdayaan Masyarakat dan Pencetakan SDM Unggul", dalam Hotmatua Daulay dan Mulyanto (ed.), Membangun SDM dan Kapabilitas Teknologi Masyarakat ISTECS,Bandung: 2001

Mubyarto, Membangun Sistem Ekonomi,: BPFE, Yogyakarta: 2000 
82 | Aye Sudarto Membangun Keluarga Utama (MKU).....

M. Dawam Rahardjo, Islam dan Transformasi Sosial-Ekonomi, Pustaka Pelajar, Yogyakarta: 1999

Muhammad dan Alimin, Etika dan Perlindungan Konsumen dalam Ekonomi Islam, BPFE Yogyakarta: 2004

Mubyarto, Ekonomi Rakyat, Program IDT dan Demokrasi Ekonomi Indonesia, Yogyakarta: Adtya Media: 1997

Muhammad, Manajemen Bank Syari'ah, edisi Revisi, UPP AMP YKPN, Yogyakarta: 2005

Muhammad, Dasar-dasar Keuangan Islami, UII, Yogyakrta, 2004

M. Nur Rianto Al Arif, S.E, M.Si, Teori Makro Ekonomi Islam, Al Fabeta, Bandung 2010

Muhammad Akram Khan, Economic Teaching of ProphetMuhammad, A Select Anthology of Hadith Literature on Economic, Terjemahan Bank Muamalat Indonesia Islamabad: International Institute of Islamnic Economicsm :1996

M. Abdul Manan, Islamic Economic Theory and Practice, Terjemahan M. Nastangin Yogyakarka: Dana Bakti Wakaf: 1993

M. Syafi'I Antonio dan Cecep Maskanul Hakim, Ekonomi Islam dalam Perspektif Sejarah, ICMIBandung: 1995 , Bank Syariah Suatu Pengenalan Umum, Tazkiya Intitut, Jakarta 1999.

Profile, BMt Assyafiiyah tahun 2018

Randy R. Wrihatnolo dan Rian Nugroho D. Menegement Pemberdayaan, Media Kompetindo, Jakarta: 2007

Sumardi Suryabrata, Metodologi Penelitian, Rajawali Press, Jakarta: 1990

Syaikh Syaifurrahman al Mubarakfiry, Sirah Nabawiyah, Terjemahan Kathur Suhardi: Pustaka Al Kautsar, Jakarta :1998

Siti Maryam dkk, Sejarah Peradaban Islam, IAIN Suka dan LESFI, Yogyakarta:2002

Syafruddin Parwiranegara, Ekonomi dan Keuangan; Makna Ekonomi Islam, Haji Masagung, Jakarta: 1988

Syibli Nu'man, Umar yang Agung, Pustaka Jaya, Bandung: 1981

UU Zakat no 23 tahun 2011.

Wawancara dengan bapak Mudofir Pendiri BMT Assyafiiyah tanggal 6 Juli 2018

Wakaf uang adalah wakaf berupa uang yang dapat dikelola secara produktif, hasilnya dimanfaatkan untuk mauquf alaih. Nazir Wakaf BMT L Risma, Tanya Jawab Wakaf Uang, Tanpa Tahun 
Ekonomica Sharia Volume 5 Nomor 1 Edisi Agustus $2019 \mid 83$

Yusuf Qordowi, Kiat Islam Mengentaskan Kemiskinan, alih bahasa Syafril Halim, Gema Insani Press, Jakarta: 1995

Yusuf Wibisono, Mengelola Zakat Indonesia, Pena Media Grup, Jakarta th 2015 